\title{
25 anos de compromisso com a ciência e a saúde coletiva!
}

No dia 29 de setembro de 2019, a Abrasco completou 40 anos. A data foi comemorada na abertura do $8^{\circ}$ Congresso Brasileiro de Ciências Sociais e Humanas em Saúde, em João Pessoa com a presença de 11 dos nossos 16 presidentes e de quatro secretários executivos. Relembramos a nossa história marcada pela trajetória de lutas pela diminuição das desigualdades sociais e para assegurar o direito universal à saúde a todas e todos os brasileiros. Não poderia ter sido mais emblemático o fato dessa comemoração acontecer na Paraíba, capital de um importante estado do Nordeste, região que tem se destacado pela força de resistência a todo o contexto de adversidade política que nosso país vem sofrendo por parte de um regime de austeridade e desmonte de políticas sociais conquistadas e construídas com muito trabalho e dedicação.

A Abrasco nasceu com o compromisso de fortalecer o campo da saúde coletiva se engajando firmemente na construção e no apoio aos programas de pós-graduação lato sensu e stricto sensu em todas as regiões do país ${ }^{1}$. A partir de 2010 também foi incluída em nossas causas a defesa dos cursos de graduação na área.

O fortalecimento de nossa área científica e a expansão da formação de profissionais comprometidos com a estruturação do campo de saúde coletiva têm marcado a nossa atuação. Acompanhamos o crescimento do número de formandos e da produção científica na área, a qual sempre mostrou o compromisso de fortalecer o nosso sistema universal de saúde. Dentro desta perspectiva que a revista Ciência \& Saúde Coletiva, que neste ano completa 25 anos, surgiu e encarou essa missão de forma exemplar. Hoje nos orgulhamos de que a nossa revista é a que está em primeiro lugar de todas as revistas científicas brasileiras segundo os indicadores do Google Scholar e também tem se destacado no índice JCR ${ }^{1}$.

Não há dúvida de que essa conquista não ocorreu por acaso, mas sim por ser uma revista científica que dialoga com as três áreas que compõem o nosso campo - políticas de saúde, epidemiologia e ciências sociais e humanas - e que recebe todos os temas inerentes às causas sociais e suas interfaces. Sua linha editorial sempre zelou por incluir artigos de alta qualidade científica, mas abertos à cultura e aos saberes populares. Temos certeza de que a trajetória de nossa prestigiada revista se deu aliando divulgação ao respeito à vida, ao fim da violência e à defesa de todos os direitos humanos e liberdades fundamentais ${ }^{2,3}$.

Sabemos bem de todas as dificuldades que vêm sendo impostas não só aos que trabalham diretamente na revista, mas também aos nossos colaboradores e à nossa comunidade científica em função dos ataques diários à ciência e à educação que estamos vivenciando nos últimos anos; no entanto, com solidariedade e determinação, seguimos adiante. Agradecemos aos que com todas estas dificuldades mantêm viva a revista e continuam acreditando que este é o caminho para garantir o papel da ciência e a liberdade de expressão.

Neste ano em que a C\&SC comemora seus 25 anos, o mundo vem sendo acometido pela pandemia de COVID-19. Mais uma vez a revista respondeu à sua missão e desde o mês de junho publicou três números especiais (dois suplementos e uma edição) sobre o tema. Foram mais de 50 artigos que mostraram a importância da nossa área no enfrentamento desta crise sanitária que é a mais grave do século.

Infelizmente, as consequências da pandemia no país têm tomado dimensões alarmantes e, no contexto de tão grave crise institucional e política em que se encontra o país, o quadro é muito preocupante. Temos, contudo, certeza de que estamos exercendo nosso papel ao difundir informação científica que incentiva o diálogo de nossa comunidade e a comunicação com a população.

Parabéns aos atuais editores, Cecilia Minayo, Romeu Gomes e Antônio Augusto Silva, e a todos os colaboradores e equipe de apoio que tornaram esta revista um patrimônio da saúde coletiva brasileira!

Continuaremos firmes na valorização da ciência e na luta pela democracia e pelo direito à saúde e à educação!

Gulnar Azevedo e Silva (https://orcid.org/0000-0001-8734-2799) 1,2

${ }^{1}$ Instituto de Medicina Social, Universidade Estadual do Rio de Janeiro. Rio de Janeiro RJ Brasil.

${ }^{2}$ Presidência, Associação Brasileira de Saúde Coletiva. Rio de Janeiro RJ Brasil.

\section{Referências}

1. Conner N, Provedel A, Maciel ELN. Ciência \& Saúde Coletiva: análise da produção científica e redes colaborativas de pesquisa. Cien Saude Colet 2017; 22(3):987-996.

2. Minayo MCS, Gomes R, Silva AAM. 25 anos de ciência para construção do SUS. Cien Saude Colet 2020; 25(3):780-780.

3. Nunes E. Fronteiras do Conhecimento e Saúde Coletiva. Cien Saude Colet 2019; 24(9):3179-3182. 